J. clin. Path. (1948), 1, 144.

\title{
THE DETERMINATION OF PACKED CELL VOLUME FROM BLOOD AND PLASMA GRAVITIES IN INDIAN SOLDIERS
}

\author{
BY \\ H. LEHMANN \\ From the General Headquarters (India) Medical Research Organization, India Command
}

(RECEIVED FOR PUBLICATION, JULY 19, 1946)

Phillips and others (1945) recommended the use of standard copper sulphate solutions for determining the specific gravity of whole blood and of plasma. From these two values they calculated the blood cell volume using Ashworth and Tigertt's (1940-1) equation :

$$
\text { -(1) } \mathrm{CV}=100 \times \frac{\mathrm{Gb}-\mathrm{Gp}}{\mathrm{Gc}-\mathrm{Gp}}
$$

where $\mathrm{CV}$ is the volume in ml. of packed cells in $100 \mathrm{ml}$. of blood, and $\mathrm{Gb}, \mathrm{Gp}$, and $\mathrm{Gc}$ are the specific gravities of the whole blood, plasma, and packed cells respectively. For Gc the normal value of 1.0970 was assumed.

The object of this investigation was to find out how far this method could be employed usefully in India Command in place of the usual haematocrit technique, which requires equipment not always available. Assessments of mean corpuscular volume based on an inspection of dry. blood films or of the cells in the counting chamber cannot be expressed in figures, and it has thus been difficult to obtain information as to the improvement or deterioration in individual cases or to compare the blood state of different groups of population.

Seventy-five samples of venous blood were taken, the red cell concentration, the haemoglobin content, and the packed cell volume were measured, and the mean corpuscular volume and mean corpuscular haemoglobin concentration calculated. The specific gravities of the whole blood and plasma were estimated by the copper sulphate method and the packed cell volume was calculated according to equation (1). The subjects were Indian soldiers, most of whom were healthy. The cases of severe anaemia were hospital patients suffering from post-dysenteric debility.

\section{Methods}

Venous blood was withdrawn without stasis into syringes sterilized not less than twenty-four hours previously by hot liquid paraffin; $2.5 . \mathrm{ml}$. was measured into a neutral glass tube marked at this volume and containing $2 \mathrm{mg}$. per $\mathrm{ml}$. of a $3: 2 \mathrm{mix}-$ ture of ammonium and potassium oxalates. All estimations were done within three hours after the collection of the blood.

Haemoglobin.-A Sahli-Adams "Hemometer" was used with square, non-fading, plano-parallel doubleglass standards. This apparatus was restandardized against bloods the haemoglobin content of which was determined by the method of King and others (1944), in which an alkaline haematin standard prepared from crystalline haemin is employed.

Red blood cells.-A Spencer's bright-line counting chamber with the improved Neubauer ruling was used. Each count was performed twice in two dilutions prepared in two different mercury calibrated pipettes.

Packed cell volume.-Wintrobe's "Hematocrit" tubes of $3 \mathrm{~mm}$. bore were used. The samples were centrifuged for one hour in a Clay-Adams "Senior Model " centrifuge at 2,500 r.p.m. 
TABLE I

DISTRIBUTION OF THE HAEMOGLOBIN AND MEAN CORPUSCULAR VOLUME LEVELS AMONGST THE 75 INDIAN SOLDIERS INVESTIGATED

\begin{tabular}{|c|c|c|c|c|c|c|c|c|}
\hline & & \multicolumn{7}{|c|}{ Haemoglobin in $\mathrm{g} . \%$} \\
\hline \multicolumn{2}{|c|}{ Number of cases } & Below 5 & $5-7.9$ & $8-9.9$ & $10-11.9$ & $12-13.9$ & $14-15.9$ & 16 and aboye \\
\hline $\begin{array}{l}\text { Mean corpuscular } \\
\text { volume in cu. } \mu\end{array}$ & $\begin{array}{c}\text { Total } \\
\text { number }\end{array}$ & & & & & & & \\
\hline $\begin{array}{c}\text { Below } 80 \\
80-99 \\
100-109 \\
110-129 \\
130-160\end{array}$ & $\begin{array}{l}4 \\
33 \\
13 \\
15 \\
10\end{array}$ & $\begin{array}{l}1 \\
2 \\
1 \\
2\end{array}$ & $\begin{array}{l}1 \\
1 \\
4\end{array}$ & $\begin{array}{l}2 \\
1 \\
3 \\
3\end{array}$ & $\begin{array}{l}3 \\
2 \\
6 \\
2\end{array}$ & $\begin{array}{l}4 \\
6 \\
3 \\
1\end{array}$ & $\begin{array}{r}1 \\
18 \\
2 \\
1\end{array}$ & $\begin{array}{l}4 \\
1\end{array}$ \\
\hline
\end{tabular}

Specific gravity.-Drops of whole blood and plasma were delivered from a capillary pipette into standard copper sulphate solutions varying in specific gravity by 0.001 . Values falling between those of two adjacent standard solutions were interpolated to the nearest 0.0002 specific gravity.* While the effect of temperature is the same on the gravity of copper sulphate solutions and of plasma, this has not yet been proved to apply to whole blood also, and as the laboratory temperature varied between 12 and $35^{\circ} \mathrm{C}$. it was noted for each measurement.

Calculation of $\mathbf{C V}$.-From the specific gravities of whole blood and plasma, CV was calculated using the above quoted equation. The added oxalates do not distribute themselves absolutely equally between cells and plasma, but this difference has only a small effect on the calculated results. The specific gravity values are given in Table II, and if wanted the corrections for oxalates according to Phillips and others (1945) can be introduced at any time. Gc was taken to be 1.0970 .

\section{Results}

Table I shows the distribution of the haemoglobin and mean corpuscular volume levels amongst the seventy-five soldiers investigated.

If one classifies a blood haemoglobin content of above $14 \mathrm{~g}$. per cent as normal, one between 12 and $13.9 \mathrm{~g}$. per cent as showing a tendency towards anaemia, and one below $12 \mathrm{~g}$. per cent as definitely anaemic, then 36 per cent of the subjects can be

* The specific gravity of blood or plasma is measured by dropping the fluid into copper sulphate solutions varying by 0.001 in gravity. For example, if a plasma drop falls in a solution of s.g. 1.024 and For example, if a plasma drop falls in a solution of s.g. 1.024 and
rises in one of s.g. 1.025, the gravity of the plasma is between 1.024 and 1.025. If it rises in the one with the same speed as it falls in the other the plasma gravity is taken to be 1.0245 . If it rises more quickly in the 1.025 solution than it falls in the 1.024 solution, the gravity is between 1.024 and 1.0245 . If it is stationary in the 1.024 bottle the gravity is 1.024 , if it is almost stationary but falls very slowly it is taken to be 1.0242 and so on. regarded as normal, 19 per cent as mildly anaemic, and 45 per cent as showing pronounced anaemia. Half the cases had a mean corpuscular volume of below $100 \mathrm{cu} . \mu$ as calculated from haematocrit values; of the other half, 33 per cent were mildly and 66 per cent severely macrocytic, having mean corpuscular volumes between 100 and 109 and between 110 and $160 \mathrm{cu} . \mu$ respectively.

Table II shows the CV values in all seventy-five cases and compares the results obtained by centrifuging and by calculating from $\mathrm{Gb}$ and $\mathrm{Gp}$.

The haemoglobin content for each sample is given, and the table is subdivided into sections according to the mean corpuscular volume. It will be seen that the $C V$ value calculated from the specific gravity is usually lower than the one obtained by measuring the packed cell volume by centrifuging. The Gc of 1.0970 used for the calculation was obviously too high for our samples. It has to be pointed out that the originators found Gc to be 1.0970 in normal heparinized bloods; it should therefore be expected to be higher rather than lower in our oxalated suspensions. Had a correction for oxalates been introduced the differences between the two CVs would be slightly greater still.

There is an association between the differences in the two CVs and the mean corpuscular volume. This difference is significant since $0.05>P>0.01$ when tested by analysis of variance. The calculated CV is on the average 5.50 less in the bloods with a mean corpuscular volume below $100 \mathrm{cu} . \mu$; the difference is -4.52 when the mean corpuscular volume is between 100 and $109 \mathrm{cu} . \mu$ and only -3.16 in the samples with mean corpuscular volumes of $110 \mathrm{cu} . \mu$ and above. 
. TABLE II

COMPARISON BETWEEN CV FOUND BY CENTRIFUGING AND CALCULATED FROM SPECIFIC GRAVITY VALUES OF BLOOD AND PLASMA

\begin{tabular}{c|c|c|c|c|c|c}
\hline $\begin{array}{c}\text { Haemoglobin } \\
\text { in } \mathbf{g} \%\end{array}$ & $\begin{array}{c}\text { Temp. } \\
\text { in }{ }^{\circ} \mathbf{C} .\end{array}$ & Gb & Gp & $\begin{array}{c}\text { CV found by } \\
\text { haematocrit }\end{array}$ & $\begin{array}{c}\text { CV calculated } \\
\text { from sp. gr. }\end{array}$ & $\begin{array}{c}\text { Difference in \% } \\
\text { CV (sp. gr.) } \\
\text { CV (haematocrit) }\end{array}$ \\
\hline
\end{tabular}

Mean corpuscular volume below $80 \mathrm{cu} . \mu$

\begin{tabular}{|c|c|c|c|c|c|c|}
\hline $\begin{array}{r}4.5 \\
8.0 \\
8.5 \\
14.4\end{array}$ & $\begin{array}{l}19.2 \\
24.9 \\
13.9 \\
14.0\end{array}$ & $\begin{array}{l}1.0380 \\
1.0480 \\
1.0432 \\
1.0545\end{array}$ & $\begin{array}{l}1.0282 \\
1.0306 \\
1.0265 \\
1.0260\end{array}$ & $\begin{array}{l}20.0 \\
32.9 \\
29.0 \\
48.0\end{array}$ & $\begin{array}{l}14.2 \\
26.3 \\
23.7 \\
40.3\end{array}$ & $\begin{array}{l}-29 \\
-20 \\
-18 \\
-16\end{array}$ \\
\hline \multicolumn{7}{|c|}{ Mean corpuscular volume $80-99 \mathrm{cu} . \mu$} \\
\hline $\begin{array}{l}4.8 \\
4.8 \\
7.5 \\
9.0 \\
10.4 \\
10.5 \\
11.0 \\
13.0 \\
13.5 \\
13.5 \\
13.8 \\
14.0 \\
14.2 \\
14.2 \\
14.2 \\
14.2 \\
14.2 \\
14.6 \\
14.8 \\
15.0 \\
15.0 \\
15.0 \\
15.1 \\
15.1 \\
15.4 \\
15.4 \\
15.6 \\
15.6 \\
15.8 \\
16.0 \\
16.0 \\
16.4 \\
16.4\end{array}$ & $\begin{array}{l}15.2 \\
34.4 \\
15.2 \\
19.1 \\
19.5 \\
15.2 \\
14.0 \\
16.0 \\
18.0 \\
15.8 \\
19.3 \\
16.0 \\
23.3 \\
23.9 \\
16.0 \\
16.0 \\
15.8 \\
15.8 \\
16.0 \\
16.0 \\
16.0 \\
14.5 \\
16.0 \\
16.0 \\
15.8 \\
16.0 \\
15.8 \\
16.0 \\
16.0 \\
15.8 \\
15.8 \\
15.8 \\
15.8\end{array}$ & $\begin{array}{l}1.0358 \\
1.0370 \\
1.0480 \\
1.0446 \\
1.0480 \\
1.0488 \\
1.0505 \\
1.0530 \\
1.0540 \\
1.0540 \\
1.0533 \\
1.0540 \\
1.0565 \\
1.0550 \\
1.0541 \\
1.0550 \\
1.0570 \\
1.0551 \\
1.0553 \\
1.0565 \\
1.0557 \\
1.0560 \\
1.0563 \\
1.0579 \\
1.0565 \\
1.0560 \\
1.0570 \\
1.0598 \\
1.0573 \\
1.0588 \\
1.0603 \\
1.0580 \\
1.0589\end{array}$ & $\begin{array}{l}1.0260 \\
1.0262 \\
1.0290 \\
1.0240 \\
1.0270 \\
1.0298 \\
1.0300 \\
1.0280 \\
1.0270 \\
1.0280 \\
1.0270 \\
1.0288 \\
1.0295 \\
1.0268 \\
1.0268 \\
1.0268 \\
1.0290 \\
1.0285 \\
1.0259 \\
1.0273 \\
1.0257 \\
1.0268 \\
1.0268 \\
1.0282 \\
1.0260 \\
1.0268 \\
1.0266 \\
1.0276 \\
1.0268 \\
1.0259 \\
1.0280 \\
1.0269 \\
1.0257\end{array}$ & $\begin{array}{l}20.0 \\
14.6 \\
29.0 \\
33.3 \\
38.0 \\
36.0 \\
38.0 \\
44.5 \\
43.0 \\
41.0 \\
45.0 \\
45.8 \\
47.5 \\
46.0 \\
45.0 \\
44.0 \\
42.0 \\
48.0 \\
49.0 \\
48.0 \\
48.0 \\
49.0 \\
47.2 \\
49.0 \\
48.0 \\
48.0 \\
48.0 \\
50.0 \\
51.0 \\
48.0 \\
51.0 \\
50.0 \\
48.0\end{array}$ & $\begin{array}{r}14.0 \\
15.0 \\
28.0 \\
28.2 \\
30.0 \\
28.3 \\
30.6 \\
36.3 \\
38.5 \\
37.7 \\
37.5 \\
37.0 \\
40.0 \\
40.1 \\
38.9 \\
40.2 \\
41.3 \\
38.9 \\
41.3 \\
41.9 \\
42.0 \\
41.7 \\
42.0 \\
43.2 \\
43.0 \\
41.7 \\
43.3 \\
46.4 \\
43.5 \\
46.4 \\
47.0 \\
44.4 \\
46.6\end{array}$ & $\begin{array}{l}-30 \\
+2 \\
\pm 3 \\
-15 \\
-21 \\
-21 \\
-19 \\
-18 \\
-10 \\
-8 \\
-17 \\
-19 \\
-16 \\
-13 \\
-14 \\
-9 \\
-2 \\
-19 \\
-16 \\
-13 \\
-12 \\
-15 \\
-11 \\
-12 \\
-10 \\
-13 \\
-10 \\
-7 \\
-15 \\
-3 \\
-8 \\
-11 \\
-3\end{array}$ \\
\hline \multicolumn{7}{|c|}{ Mean corpuscular volume $100-109 \mathrm{cu} . \mu$} \\
\hline $\begin{array}{r}3.7 \\
7.6 \\
10.1 \\
10.5 \\
12.0 \\
12.0 \\
12.7 \\
12.8 \\
13.3 \\
13.8 \\
14.0 \\
14.0 \\
16.5\end{array}$ & $\begin{array}{l}14.1 \\
16.4 \\
15.2 \\
11.7 \\
14.5 \\
14.5 \\
18.2 \\
14.1 \\
18.2 \\
15.5 \\
16.1 \\
23.2 \\
35.3\end{array}$ & $\begin{array}{l}1.0305 \\
1.0412 \\
1.0489 \\
1.0488 \\
1.0522 \\
1.0515 \\
1.0539 \\
1.0530 \\
1.0540 \\
1.0578 \\
1.0518 \\
1.0530 \\
1.0576\end{array}$ & $\begin{array}{l}1.0230 \\
1.0270 \\
1.0279 \\
1.0270 \\
1.0295 \\
1.0300 \\
1.0295 \\
1.0283 \\
1.0290 \\
1.0308 \\
1.0250 \\
1.0250 \\
1.0270\end{array}$ & $\begin{array}{l}11.5 \\
22.0 \\
33.0 \\
31.8 \\
42.5 \\
41.0 \\
39.0 \\
45.0 \\
40.0 \\
41.5 \\
44.9 \\
44.6 \\
49.0\end{array}$ & $\begin{array}{l}10.1 \\
20.2 \\
30.7 \\
31.1 \\
33.6 \\
32.1 \\
36.2 \\
35.9 \\
36.8 \\
40.7 \\
37.2 \\
38.9 \\
43.5\end{array}$ & $\begin{array}{l}-12 \\
-8 \\
-7 \\
-2 \\
-21 \\
-22 \\
-7 \\
-20 \\
-8 \\
-2 \\
-17 \\
-13 \\
-11\end{array}$ \\
\hline
\end{tabular}


TABLE II-continued

\begin{tabular}{|c|c|c|c|c|c|c|}
\hline $\begin{array}{l}\text { Haemoglobin } \\
\text { in } \mathrm{g} . \%\end{array}$ & $\begin{array}{l}\text { Temp. } \\
\text { in }{ }^{\circ} \mathbf{C} \text {. }\end{array}$ & Gb & Gp & $\begin{array}{l}\text { CV found by } \\
\text { haematocrit }\end{array}$ & $\begin{array}{l}\text { CV calculated } \\
\text { from sp. gr. }\end{array}$ & $\begin{array}{l}\text { Difference in \% } \\
\text { CV.(sp. gr.) } \\
\text { CV (haematocrit) }\end{array}$ \\
\hline
\end{tabular}

Mean corpuscular volume $110-129 \mathrm{cu} . \mu$

\begin{tabular}{|c|c|c|c|c|c|c|}
\hline $\begin{array}{r}2.2 \\
4.8 \\
9.0 \\
9.0 \\
9.6 \\
10.1 \\
10.2 \\
10.7 \\
11.2 \\
11.5 \\
11.7 \\
12.6 \\
13.0 \\
13.1 \\
14.8\end{array}$ & $\begin{array}{l}16.0 \\
15.4 \\
15.9 \\
18.2 \\
27.5 \\
15.9 \\
14.1 \\
17.8 \\
15.3 \\
13.4 \\
23.1 \\
15.3 \\
15.0 \\
15.0 \\
15.1\end{array}$ & $\begin{array}{l}1.0298 \\
1.0400 \\
1.0442 \\
1.0472 \\
1.0460 \\
1.0508 \\
1.0466 \\
1.0475 \\
1.0515 \\
1.0508 \\
1.0522 \\
1.0515 \\
1.0510 \\
1.0515 \\
1.0552\end{array}$ & $\begin{array}{l}1.0256 \\
1.0300 \\
1.0255 \\
1.0275 \\
1.0260 \\
1.0300 \\
1.0249 \\
1.0222 \\
1.0305 \\
1.0270 \\
1.0310 \\
1.0249 \\
1.0260 \\
1.0280 \\
1.0280\end{array}$ & $\begin{array}{r}7.5 \\
15.5 \\
24.0 \\
30.8 \\
32.0 \\
32.5 \\
36.0 \\
36.5 \\
37.0 \\
35.5 \\
37.0 \\
40.5 \\
38.5 \\
39.5 \\
45.0\end{array}$ & $\begin{array}{r}5.9 \\
14.9 \\
26.2 \\
28.4 \\
28.2 \\
31.0 \\
30.1 \\
33.9 \\
31.5 \\
34.0 \\
32.1 \\
36.8 \\
35.3 \\
34.5 \\
39.5\end{array}$ & $\begin{array}{r}-21 \\
-44 \\
+14 \\
-8 \\
-12 \\
-5 \\
-16 \\
-7 \\
-15 \\
-7 \\
-13 \\
-12 \\
-8 \\
-13 \\
-12\end{array}$ \\
\hline \multicolumn{7}{|c|}{ Mean corpuscular volume above $130 \mathrm{cu} . \mu$} \\
\hline $\begin{array}{r}6.0 \\
6.4 \\
7.0 \\
7.4 \\
9.2 \\
9.5 \\
9.8 \\
10.5 \\
11.4 \\
13.3\end{array}$ & $\begin{array}{l}13.8 \\
16.5 \\
12.8 \\
23.4 \\
23.9 \\
15.1 \\
14.5 \\
18.9 \\
14.5 \\
12.1\end{array}$ & $\begin{array}{l}1.0370 \\
1.0378 \\
1.0380 \\
1.0440 \\
1.0478 \\
1.0478 \\
1.0493 \\
1.0490 \\
1.0502 \\
1.0540\end{array}$ & $\begin{array}{l}1.0250 \\
1.0230 \\
1.0220 \\
1.0288 \\
1.0278 \\
1.0280 \\
1.0283 \\
1.0269 \\
1.0270 \\
1.0270\end{array}$ & $\begin{array}{l}18.5 \\
20.0 \\
22.0 \\
23.5 \\
28.6 \\
34.0 \\
35.0 \\
36.8 \\
40.0 \\
47.0\end{array}$ & $\begin{array}{l}16.7 \\
20.0 \\
21.4 \\
22.3 \\
28.9 \\
28.7 \\
30.6 \\
31.5 \\
33.1 \\
38.5\end{array}$ & $\begin{array}{l}-10 \\
\pm 0 \\
\pm 3 \\
-5 \\
+1 \\
-16 \\
-12 \\
-14 \\
-17 \\
-18\end{array}$ \\
\hline
\end{tabular}

There is in this series the usual association between high and low mean corpuscular volume and high and low mean corpuscular haemoglobin concentration. Therefore there is a tendency for

the difference between the two CVs to rise the less haemoglobin the cells contain-that is, the more Gc becomes an expression of the gravity of the non-haemoglobin protein of the blood cells (see also Chart).

If the calculated $\mathrm{CV}$ values are multiplied with a factor of 1.1 more satisfactory agreement with the true $\mathrm{CV}$ is obtained.

In the Chart is shown the scatter of the mean corpuscular volume values based on $\mathrm{CV}$ haematocrit and on the $\mathrm{CV}$ (specific gravity) calculated according to the equation

$$
\mathrm{CV}=110 \times \frac{\mathrm{Gb}-\mathrm{Gp}}{1.0970-\mathrm{Gp}}
$$

where $G b$ and $G p$ are again the specific gravity of the oxalated blood and plasma respectively. The values obtained from blood having a mean corpuscular haemoglobin concentration of 30 per cent and above are entered as 0 , those of bloods showing a mean corpuscular haemoglobin concentration below 30 per cent are shown as $\boldsymbol{\Lambda}$. The diagonal line represents ideal agreement and all values should be found on it if the method were perfect. It will be seen that while the values are about equally scattered above and below the line of ideal agreement, divergencies in either direction are considerable. The figure also demonstrates that even on using the corrected equation a low mean corpuscular haemoglobin concentration tends to place the calculated results below the true value.

Table III shows the ranges in which mean corpuscular volumes based on equation (2) fall when compared with the true values. Seventy-two out of seventy-five cases fall within the limit set out in Table III. The three exceptions are the first two samples in Group 2 of Table II and the first sample in Group 4. All three samples have a haemoglobin content of below $5 \mathrm{~g}$. per cent. 
TABLE III

THE RANGE WITHIN WHICH MEAN CORPUSCULAR VOLUMES FALL WHEN BASED ON CV VALUES CALCULATED FROM EQUATION (2)

\begin{tabular}{c|c|c|c}
\hline $\begin{array}{c}\text { Number } \\
\text { of } \\
\text { cases }\end{array}$ & $\begin{array}{c}\text { True mean } \\
\text { corpuscular } \\
\text { volumes } \\
\text { (derived from } \\
\text { haematocrit } \\
\text { CV) in cu. } \mu\end{array}$ & $\begin{array}{c}\text { Range of mean } \\
\text { corpuscular } \\
\text { volumes } \\
\text { calculated from } \\
\text { specific gravities }\end{array}$ & $\begin{array}{c}\text { Number } \\
\text { of } \\
\text { exceptions }\end{array}$ \\
\hline 4 & $70-79$ & $60-75$ & \\
\hline 33 & $80-99$ & $75-105$ & 2 \\
13 & $100-109$ & $85-110$ & $105-140$ \\
15 & $110-129$ & $100-175$ & 1 \\
10 & $130-160$ & $120-175$ & \\
\hline
\end{tabular}

It will be seen that in our hands the method of calculating CV and mean corpuscular volume from specific gravity was not accurate enough to differentiate normocytosis from macrocytosis and microcytosis respectively. Whereas the difference between the Gc in our samples from that given by the originators may be compensated by introducing the factor 1.1 into the original equation, no singlecorrection can reduce the wide margin within which calculated results are obtained on either side: of the true values.

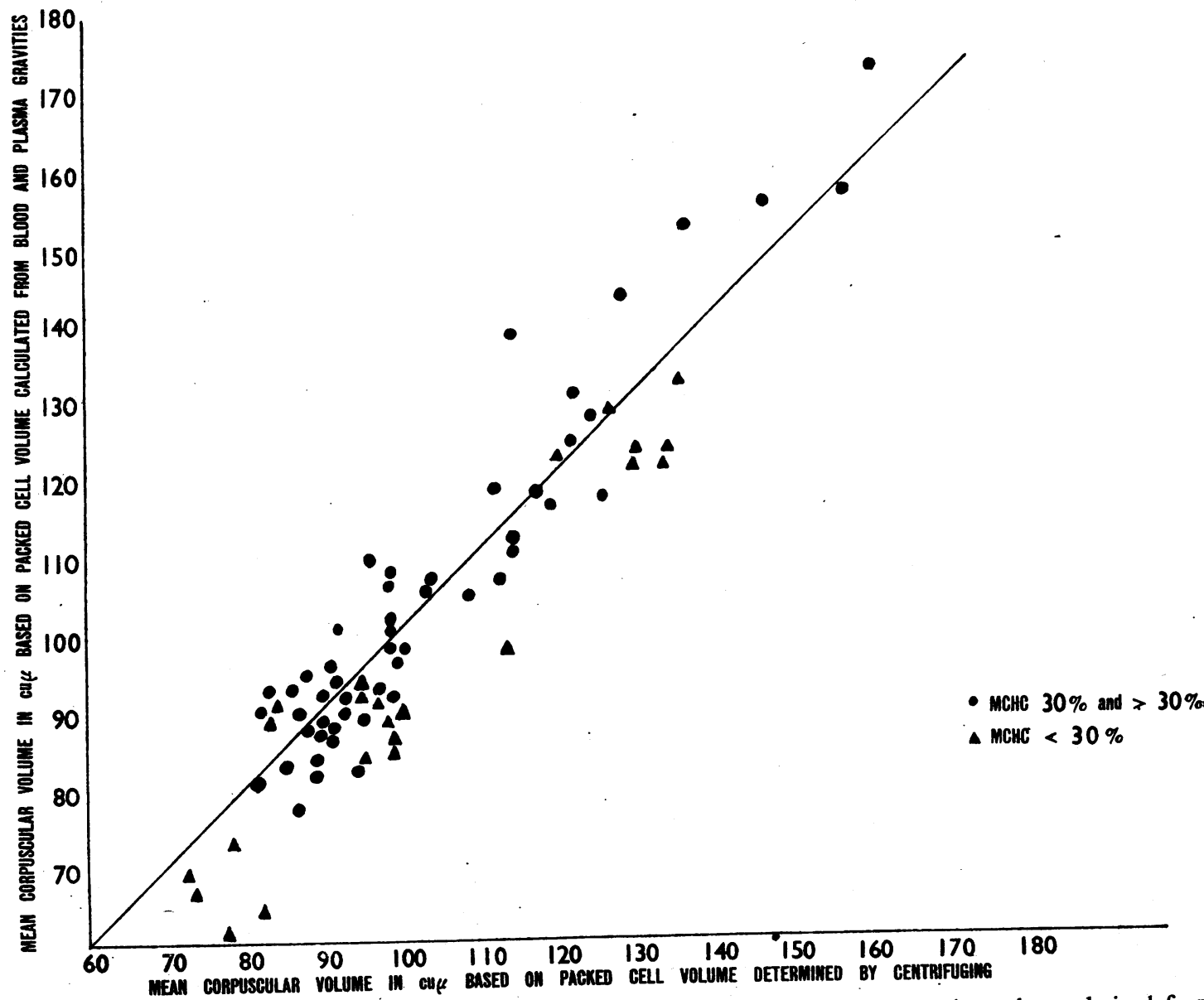

CHART.-The range within which agreement can be obtained between mean corpuscular volume derived from the haematocrit value and mean corpuscular volume based on a CV calculated from blood and plasma. gravities. The influence of mean corpuscular haemoglobin concentration on this agreement is also shown.

Abscisse: Mean corpuscular volume in cu. $\mu$ derived from haematocrit values.

Ordinate. Mean corpuscular volume in cu. $\mu$ calculated from specific gravities.

mean corpuscular haemoglobin concentration, 30 per cent and above. mean corpuscular haemoglobin concentration, 30 per 30 per cent. 


\section{Summary}

1. The haemoglobin content, the red cell concentration, the haematocrit value, the mean corpuscular volume, the mean corpuscular haemoglobin concentration, and the specific gravities of blood and plasma of seventy-five Indian soldiers were determined. Some of the subjects were hospital patients.

2. Nineteen per cent of the subjects were mildly, and 45 per cent more severely, anaemic. The mean corpuscular volume was below $100 \mathrm{cu}$. $\mu$ in one-half of the cases ; of the other half, onethird showed slight and two-thirds considerable macrocytosis.

3. The CV values ( $\mathrm{ml}$. of packed cells in $100 \mathrm{ml}$. of blood) found by centrifuging (CV haematocrit) were compared with those calculated from blood and plasma gravities (CV specific gravity).

4. The CV (specific gravity) was generally 10 per cent lower than the CV (haematocrit). The per cent differences increased with smaller mean corpuscular volume and lower mean corpuscular haemoglobin concentration.

5. It is suggested that the differences between the haematocrit $\mathrm{CV}$ and $\mathrm{CV}$ determined from specific gravities were due to the cell gravities in the samples being below 1.0970, the value given for normal cell gravity by previous authors, and that these cell gravities were the lower the more they depended on the non-haemoglobin protein of the cells.

6. The difference between the haematocrit and gravity cell volumes could be fairly satisfactorily compensated by the introduction of the factor 1.1 into the equation from which $\mathrm{CV}$ specific gravity is calculated. However, mean corpuscular volumes based on CV specific gravity obtained in this way still diverged too widely on either side of the figures obtained from haematocrit values to make the calculation a useful method for clinical purposes.

This investigation was carried out at the suggestion of Lieut.-Col. B. L. Taneja, I.M.S./I.A.M.C., Assistant Director of Pathology, North-Western Army, India Command. I am indebted to Major M. Hynes, R.A.M.C., Officer Commanding the G.H.Q. Anaemia Investigation Team, India Command, for his interest and advice, and to Dr. W. J. Martin for statistical analysis. Sergeant Kayser, R.A.M.C., was responsible for the red cell counts, and I should like to thank him for this and other help throughout the investigation. My thanks are due to the Director of Medical Services in India for permission to publish this paper.

\section{REFERENCES}

Ashworth, C. T., and Tigertt, W. D. (1940-1). J. Lab. clin. Med., 26,

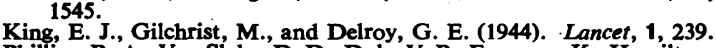
Phillips, R. A., Van Slyke, D. D., Dole, V. P., Emerson, K., Hamilton, P. B., and Archibald, R. M. (1945). "Copper Sulfate Method for Measuring Specific Gravities of Whole Blood and Plasma." New York. Josiah Macy Jr. Foundation. 